\title{
SOCIAL LIFE OF PEOPLE WITH DIAGNOSIS OF SCHIZOPHRENIA, ATTENDED AT A PSYCHOSOCIAL CARE CENTER
}

Marciana Fernandes Moll ${ }^{1}$ Toyoko Saeki

Moll MF, Saeki T. Social life of people with diagnosis of Schizophrenia, attended at a psychosocial care center. Rev Latino-am Enfermagem 2009 novembro-dezembro; 17(6):995-1000.

This qualitative research aimed to investigate the social life of patients with a diagnosis of schizophrenia at a Psychosocial Care Center (CAPS), and identify how the therapeutic process offered by the CAPS has contributed to their social lives. The subjects of the study were patients with schizophrenia, between eighteen and forty years of age and registered at the CAPS in Uberaba, Brazil. The data were collected through a semi-structured interview. Three categories were identified: the patients' life before and after the illness, their everyday life outside CAPS and CAPS care contributing to their social life and stabilization of symptoms. The results showed that the CAPS regimen enhances treatment compliance and decreases hospitalization. However, social functioning for schizophrenic patients occurs within the family and treatment contexts. This reality evidences the need for a partnership with the Family Health Strategy and the community to improve socialization.

DESCRIPTORS: mental disorders; Schizophrenia; quality of life; nursing

\section{LA VIDA SOCIAL DE PERSONAS CON DIAGNÓSTICO DE ESQUIZOFRENIA: USUARIOS DE UN CENTRO DE ATENCIÓN PSICOSOCIAL}

Esta es una investigación cualitativa, cuyos objetivos fueron investigar la vida social de personas con diagnóstico de esquizofrenia, usuarias de un Centro de Atención Psicosocial (CAPS) e identificar como el proceso terapéutico, ofrecido por el CAPS, colabora con la vida social de esas personas. Participaron del estudio individuos con esquizofrenia, con edades entre los 18 y 40 años, matriculados en el CAPS de Uberaba, Brasil. Se utilizó la entrevista semiestructurada que originó tres categorías: vida de los pacientes antes y después de enfermarse, cotidiano de los usuarios en el ambiente fuera del CAPS y asistencia del CAPS, colaborando en la vida social y en la estabilización de síntomas. Se detectó que la terapéutica empleada colabora para la adhesión al tratamiento y reduce las internaciones psiquiátricas, sin embargo la vida social de esas personas ocurre en el contexto familiar $y$ en el ambiente de tratamiento. Esa realidad muestra la necesidad de trabajar en conjunto con la Estrategia Salud de la Familia y la comunidad para ampliar intervenciones socializantes.

DESCRIPTORES: trastornos mentales; esquizofrenia; calidad de vida; enfermería

\section{A VIDA SOCIAL DE PESSOAS COM DIAGNÓSTICO DE ESQUIZOFRENIA, USUÁRIAS DE UM CENTRO DE ATENÇÃO PSICOSSOCIAL}

Esta é pesquisa qualitativa, cujos objetivos foram: investigar a vida social de pessoas com diagnóstico de esquizofrenia, usuárias de um Centro de Atenção Psicossocial (CAPS) e identificar como o processo terapêutico, oferecido pelo CAPS, colabora na vida social dessas pessoas. Participaram do estudo indivíduos com esquizofrenia, na faixa etária de dezoito a quarenta anos, matriculados no CAPS de Uberaba, Brasil. Utilizou-se a entrevista semiestruturada que originou três categorias: vida dos pacientes antes e após o adoecimento, cotidiano dos usuários no ambiente extra CAPS e assistência do CAPS, colaborando na vida social e na estabilização de sintomas. Detectou-se que a terapêutica empregada colabora para a adesão ao tratamento e redução das internações psiquiátricas, mas a vida social dessas pessoas ocorre no contexto familiar e no ambiente de tratamento. Essa realidade mostra a necessidade de parcerias junto à Estratégia Saúde da Família e à comunidade para ampliar intervenções socializantes.

DESCRITORES: transtornos mentais; esquizofrenia; qualidade de vida; enfermagem

Escola de Enfermagem de Ribeirão Preto, Universidade de São Paulo, WHO Collaborating Centre for Nursing Research Development, Brazil: ${ }^{1} \mathrm{RN}$, Master's Student, e-mail: mrcna13@yahoo.com.br. ${ }^{2} \mathrm{RN}$, Faculty, e-mail: maryto@eerp.usp.br. 


\section{INTRODUCTION}

A historical survey of mental disorders reveals mentions of some symptoms that are today associated with schizophrenia in Hindu and Greek texts, in the period before Christ. As from the XIX century, however, more precise descriptions emerged that outlined schizophrenia as it is known today ${ }^{(1)}$.

Schizophrenia is a severe and persistent illness that causes psychotic behaviors and different difficulties in terms of interpersonal relationships, information processing and problem solving, among others. According to this assertion, schizophrenia is a psychotic disorder, as psychosis is defined according to a patient's perception of reality and the behavior deriving from this perception ${ }^{(2)}$.

The psychotic disorder under analysis starts between adolescence and the beginning of adult life (generally between 13 and 28 years of age), considerably impairing patients' regular participation in social activities, which are essential for their lives, such as studying, maintaining love relationships and interacting in groups of friends, among others ${ }^{(3)}$.

One of the main evidences of the schizophrenia prognosis is impaired social adjustment, which can be evidenced by various patients living in the community nowadays, with severe disabilities and signs of low levels of social functioning ${ }^{(4)}$.

In view of the above, some patients display social adaptation difficulties, expressed through different social behaviors. A description of practical experiences during this study reveals that many patients hospitalized for a long time are currently being treated in community services, where they participate in activities like parties and different therapeutic groups. They acquired some degree of autonomy that allows them to manage their own lives, even if partially. Another perception is related to patients with an unfavorable evolution, due to their lesser propensity to psychosocial approaches.

Psychosocial approaches cover a set of actions capable of offering patients with better social and professional integration and, consequently, better quality of life, in view of the limits the disease imposes $^{(1)}$.

When looking at patients' social life, social relations were focused on, as well as the ability to include schizophrenia patients in social events, as well as their capacity for group interaction (friends, religion, among others), which seems to be one of the objectives of treatment centered on psychosocial approaches.

The above shows that schizophrenia is considered a severe mental disorder, not only because of its symptom characteristics, but also because of the reality it imposes on the patients, making them fragile to the circumstances in their environment, which can jeopardize their autonomy, directly or indirectly affecting various spheres in their lives.

A bibliographic review on the research theme reveals a restricted number of studies focusing on these clients' social life. A literature review study in the Annals of the Meetings of Mental Health Researchers and Meetings of Psychiatric Nursing Specialists, promoted by the University of São Paulo at Ribeirão Preto College of Nursing, revealed that the theme meeting participants most addressed was related to Care Practices ${ }^{(5)}$. This reality justifies the relevance of investigating how patients themselves assess their lives, focusing on what they consider important for themselves as, nowadays, they are being offered new treatment alternatives, centered on psychosocial rehabilitation.

One innovative treatment device, whose objectives center on psychosocial rehabilitation, is the Psychosocial Care Center (CAPS), regulated by Decree 336 , issued on February $19^{\text {th }} 2002^{(6)}$.

The CAPS is "a space for creativity, for constructing life, new knowledge and practices. Instead of excluding, medicalizing and disciplining, it should welcome, take care and build bridges with society"(7)

In view of the above, this study aimed to: investigate the social life of people with a diagnosis of schizophrenia at a Psychosocial Care Center and identify how the therapeutic process offered by that Center has supported these people's social life.

This study is considered important as the CAPS is part of a new care proposal that should offer treatment that values social reinsertion and better living conditions for users attended in this therapeutic space. Based on this new care conception, practices aim to favor social adjustment and, consequently, the social life of mental disorder patients, instead of the mere abolition of symptoms.

\section{METHOD}

This descriptive and exploratory research followed a qualitative approach. Description and 
exploration permit the identification of problems, establishing relations between variables. In the light of theoretical analysis, this improves knowledge on the study object.

During participant observation, the researchers used patient records to survey data for selecting patients to participate in the interviews, adopting the following inclusion criteria: patients between 18 and 40 years old, with a diagnosis of schizophrenia and registered at the Psychosocial Care Center in Uberaba. This age range was chosen due to the fact that most reports on social interaction difficulties came from people in this age range, proposed during the "News Workshop".

Data were collected after approval for the project was obtained from the Ethics Committee for Research involving Human Beings at the Ribeirão Preto College of Nursing. Semistructured interviews were used for data collection. Interviews were held between June and November 2007, at the CAPS, and were recorded, after obtaining the participants' informed consent.

After initial reading to obtaining a general view on the obtained contents, the researcher fully transcribed the tapes recorded during the interviews with a view to data analysis. Next, data were subject to thematic analysis for discussion purposes, based on the following steps: data collation, data classification and analysis categories ${ }^{(8)}$.

\section{RESULTS AND DISCUSSIONS}

Research participants were 12 patients, using the saturation criterion, according to which interviews should be held until the researcher perceives that no new data are being collected $^{(9)}$.

The interviews revealed that patients expressed their everyday life, the changes that occurred after they got ill and the way in which the therapeutic process proposed by the CAPS had contributed to their social life and the stabilization of their symptoms, as observed through the thematic categories that emerged from their statements.

The patients' social life before and after getting ill

The interviewees kept on living with their relatives after getting ill, leading to demonstrations of satisfaction, mainly because they did not experience changes in family relationships, as expressed in the following testimony.

Before, I used to live with my mother, with my family, and I live with my sisters today, because my mother died, but they treat me well and I like that (E2).

It should be emphasized that the current psychiatric reform context attempts to recreate existing relations between the family, society and mental disorder patients ${ }^{(10)}$.

Nowadays, the family's alliance in treatment is prioritized, so as to allow patients to develop their potentials, strengthening their social relations in a community environment ${ }^{(11)}$.

Thus, it is undeniable that the family should be included in the follow-up and treatment of mental disorder patients.

It is observed, however, that relations seem to occur between patients and their relatives only, which does not permit a broader social network for these patients.

In this sense, they mention that social exchanges should occur not only at home, but also on the streets, in markets, the community and social networks ${ }^{(10)}$.

When specifying the patient's participation in social events, some difficulties were observed, which can be identified in a number of statements.

Before, I used to go out and go to parties and, today, sometimes I go for a walk close to my home, because I got weaker due to the drugs and I feel very sleepy... (E11). We used to travel a lot with people from church, but I do not have the force to do anything today... (E9).

This kind of statements was frequent, which can indicate the patients' difficulties to keep on participating in social events after getting ill, considering that the disease entailed limitations caused by symptoms and/or drugs effects.

When reflecting on the importance of the CAPS in these patients' social reinsertion, it is perceived that this treatment space should offer resources for a dignified life, using different therapeutic practices.

One interviewee's report is important, who expressed a significant change in her life after getting ill. This change derived from her regular participation in therapeutic activities proposed by the CAPS.

Before I got ill, I could never go out... After I got ill and adapted to the drugs ..., I manage to participate in church activities and go out with some of my friends... (E10). 
When looking at these subjects' participation in the job market, their difficulties to find a place in the formal job market are apprehended. Below are some statements in this sense.

...I used to work a lot to sustain my home and, today, I help the brothers in church because I have a church at home... (E8). I used to work as a secretary before, but now I help my mother to take care of the house and sometimes, I do some manicuring... (E4).

The interviewed subjects expressed their difficulties to get inserted in the job market, as none of them could show a formal job. This reality is very frequent and one of the most affected social areas tends to be job performance ${ }^{(12)}$.

This reality gave rise to protected work in the scenario of the Brazilian psychiatric reform, constituting yet another therapeutic resource. Its goal is focused on socialization, expression and social insertion through workshops. In this sense, social cooperatives are another alternative, aiming for the social integration of disadvantaged citizens in the job market by offering work $^{(13)}$.

The final relevant aspect refers to extra-family relations, considering the presence of friends and/or boyfriends in the interviewees' lives. What this aspect is concerned, before getting ill, they had friends, who were present in their everyday life. Today, however, this presence is very rare or even inexistent and patients attribute this situation to their disease. Sometimes, they said they considered their relatives as their only friends.

I had friends mainly at work, but I lost contact with them because I don't feel up to it, not even to talk and I don't know them anymore... (E5).

Mental disorders are still targets of social discrimination because they make people feel uncomfortable, not only out of fear for the unknown, but because they refer to something permeated by beliefs and prejudices, mainly with respect to schizophrenia(14). $^{(14)}$

In the same way as they mentioned difficulties to maintain friendship relations after getting ill, the interviewees also expressed difficulties to date, which often was not frequent before they got ill.

Sometimes I even had a date! But I didn't have any boyfriends anymore after I got ill... (E11).

Differently from other participants, one interviewee mentioned she got married after getting ill.

I always liked to date, but I wanted to have a serious relationship. And, today, I got married and I'm four months pregnant... (E10).
In general, it can be identified that the disease produced significant modifications in the patients' lives, considering that their reports expressed difficulties to maintain extra-family relations, to participate in social events and, mainly, to remain active in the job market.

Everyday life of users outside CAPS

This is considered a relevant discussion to outline the reach of psychosocial approaches for the social reinsertion of mental disorder patients.

Patients presented their social relations in and outside the CAPS in a clear and objective way. During their stay inside the CAPS, most of them made new friends. These meetings, however, only occurred inside the CAPS, in accordance with the following report.

I have friends here and I like everybody, but it is difficult to meet them out there; sometimes someone visits me at home... (E4).

It can be observed that the activities offered at the CAPS favor bonding between patients, but socializations are restricted to the CAPS environment. This permits reflections about partial social reinsertion, mainly because the interviewees expressed not having friends outside the CAPS, centering the friendship cycles in the family, in line with the following statements.

I only have my wife as a friend and I only leave when my wife goes with me... (E5).

I don't have friends and my family is very big and I always go out and talk to them... (E12).

Strengthening family bonds is very important, which will favor the patient's treatment. However, through treatment, it is considered important for patients to seek extra-family bonds so as to enrich their social life.

It is also relevant to present the activities patients perform outside the CAPS as, formerly, rehabilitation was understood as the individual's return to the previous state or even to normality, in terms of social and professional activities. Today, psychosocial rehabilitation is considered to be a facilitating process for users with limitations, in the sense of improving their autonomy to perform functions in the community ${ }^{(15)}$.

A wide range of activities is developed outside the CAPS and all interviewees concentrate their time on housework and religious activities. Even at weekends, they seek activities, which they call leisure, as expressed below. 
I clean my house and I also spend time with my brothers and nephews (E4). I spend time in church and I meet with the brothers to pray (E8). I go for a walk at Abbey Square with my cousin and, sometimes, I go to mass... (E11).

Despite this reality, which seems to be positive, social participation does not allow these people to expand their cycle of friends and, once again, the family's presence during these activities is emphasized.

CAPS care contributing to clients' social life and stabilization of symptoms

Among activities offered by the CAPS, the ones patients considered most favorable were group psychotherapy, medication therapy, medical appointments, handicraft workshops and parties.

Group psychotherapy allows the patient group to obtain emotional resources to face everyday reality, which seems to approach them to a more active social life, as expressed next.

I take group therapy with the psychologist and I talk a lot, talking friendly to whoever feels discouraged, I talk a lot... (E4).

Another activity they mentioned was medication therapy. In their perspective, the nursing team at the CAPS not only administers the medication, but also advises on the correct way to use it at home, and emphasizes the importance of this practice to stabilize symptoms.

...I get my medicines from the nursing technician, who explains how I should take them at home and cheers me up to continue treatment and get well... (E5).

The nursing team should center its actions not only on medication administration or on help with food or hygienic care, but on offering care that focuses on patients' autonomy in all spheres of life. These actions can center on orientations that reinforce life practices to favor self-care, correct medication use and effective participation in treatment.

Medical appointments are also frequently mentioned, granting patients the freedom to express themselves, as illustrated by one of these reports.

... I go to the doctor who listens to me without judging and prescribes the medicines correctly... (E7).

Handicraft workshops were also indicated as an important therapeutic resource.

... the workshop does a lot of good and I even teach people to make carpets I make here and at home to sell... (E11).
The workshops work to allow the participants involved to establish self-care, work and affective contact with others, which configures their social objective in combination with the clinical objective ${ }^{(16)}$.

These statements reveal that handicraft workshops are activities that permit social contact among people with mental disorders, exercising citizenship, promoting the expression of freedom and making people have contact through their productions.

Finally, the parties promoted at the service should be highlighted. These seem to be one of the most significant resources to enrich the interviewees' social life.

... I don't lose any part and I even help when they need help... (E11)

The above statement shows that socializing activities like parties are part of this important social rehabilitation proposal, as they raise patients' selfesteem, making them feel capable of exercising some social functions. Therefore, patients need to be stimulated to participate in these activities.

The perception on how the CAPS helped them, from a psychosocial and clinical perspective revealed that many patients mentioned decreased psychotic symptoms and crises.

The use of my drugs which do not let me feel so much schism, and I only managed that here at the CAPS (E12).

The experience of the mental disease symptoms is accompanied by deep suffering, despair, nervousness, impairing patients' daily experiences Minimizing these symptoms contributes to the social participation of mental disorder patients ${ }^{(17)}$.

Thus, the presence of psychotic symptoms makes it difficult for patients to participate in social and/or job events, resulting in a poorer social life. However, the collected statements and literature data reveal that remission of these symptoms favored the interviewees' social life.

Decreased hospitalizations seem to be one of the positive results of the proposed treatment, as the report below expresses.

Coming here, I follow the treatment correctly; as a result, I don't get worse and I don't have to get hospitalized... I haven't been at a psychiatric hospital for four years (E2).

In view of these considerations and statements, the CAPS significantly contributes to enrich the lives of users with a diagnosis of schizophrenia, besides mitigating the changes interfering in the different spheres of their lives. 


\section{FINAL CONSIDERATIONS}

It seems to be essential to emphasize that CAPS actions, especially handicraft workshops and socialization events, are activities that facilitate the relation between users, professionals and relatives. Furthermore, the contributions of the therapeutic resources proposed by the CAPS are highlighted to achieve treatment adherence reduce psychiatric hospitalizations.

Based on the reality presented by the study participants, it is verified that these patients' social life centers on the family context and the CAPS environment, revealing difficulties to interact socially with the community.

In this sense, CAPS teams should reflect on the need to establish intersectorial partnerships with the Family Health Strategy and the community itself, so as to offer patients the opportunity to expand their therapeutic possibilities related to socialization. Investments are needed to remove the myth surrounding schizophrenia, which the authors believe could allow these people to expand their social life.

\section{REFERENCES}

1 Louzã MR Neto, Elkis H. Psiquiatria básica. 2a ed. Porto Alegre: Artmed; 2007.

2 Stuart GW, Laraia MT. Enfermagem psiquiátrica: princípios e prática. 6a ed. Porto Alegre: Artmed; 2001.

3 Fontana AM. Manual de clínica em psiquiatria. São Paulo: Atheneu; 2005.

4 Menezes PR. Prognóstico da esquizofrenia. Rev Bras Psiquiatria 2000; 22(2)18-20.

5 Munari DB, Oliveira NF, Mello R, Saeki T, Souza MCBM. Analysis of scientific production of mental health researcher and psychiatric nursing specialist meetings. Rev Latino-am Enfermagem 2008; 16(3)471-6.

6 Ministério da Saúde (BR). Secretaria Executiva. Secretaria de Atenção à Saúde. Legislação em saúde mental: 19902004. $4^{a}$ ed. Brasília: MS, 2004

7 Rocha RM. Enfermagem em saúde mental. 2a ed. Rio de Janeiro: Senac Nacional; 2005.

8 Minayo MCS organizador. Pesquisa social: teoria, método e criatividade. 20a ed. Petrópolis: Vozes; 2002.

9 Patton MQ. Qualitative evaluation and research methods. Londres: Sage Publications; 1990.

10 Vianna PCM, Barros S. O significado do cuidado para a família na reabilitação psicossocial do doente mental: uma revisão teórica. Rev Min Enferm 2004 janeiro/março; 8(1)223-8.

11 Gonçalves E, Kantorski LP, Heck RM. Princípios que norteiam a prática em saúde mental de uma equipe do programa de saúde da família junto a familiares de indivíduos com transtorno mental severo. Rev Fam Saúde Desenv 2003, maio/ agosto; 5(2)93-102.

12 Gulinelli A, Ratto LRC, Menezes PR. O ajustamento social de pessoas com transtornos mentais graves em São Paulo, Brasil. Rev Bras Psiquiatr 2005; 27(4)309-14.

13 Valladares ACA, Lappan-Botti NC, Mello R, Kantorski LP, Scatena MCM. Reabilitação social através das oficinas terapêuticas e/ou cooperativas sociais. Rev Eletrônica Enferm 2003; 5(1)4-9.

14 Paiva AS, Stefanelli MC, Arantes EC. Grupo familiar na convivência com o doente mental: programa de educação em saúde. Família, Saúde e Desenvol 1999; 2(1)21-9.

15 Jorge MSB, Randemark NFR, Queiroz MVO, Ruiz EM. Reabilitação psicossocial: visão da equipe de saúde mental. Rev Bras Enferm 2006 novembro/dezembro; 59(6)734-9. 16 Mendonça TCP. As oficinas na saúde mental: relato de uma experiência na internação. Rev Psicol: ciência e profissão 2005 dezembro; 25(4)626-35.

17 Gentile C, Pereira MAO. A doença mental: visão de pacientes psicóticos. Cogitare Enfermagem 2005; 10(2)17-23. 